\title{
Development of Muffins from Wheat Flour and Coconut Flour using Honey as a Sweetener
}

\author{
H. N. Ramya* and S. Anitha \\ Dept. of Food Science \& Technology, College of Agriculture, \\ Hassan - 573225, Karnataka, India \\ *Corresponding author
}

\section{A B S T R A C T}

\begin{tabular}{|l|}
\hline Ke y w o r d s \\
Coconut Flour, \\
Honey, Muffins, \\
Physico - chemical \\
properties, Sensory \\
evaluation
\end{tabular}

Coconut flour is an excellent source of unique taste and aroma and rich in vitamins, minerals and dietary fibers, which might have potential application in baking products and human nutrition. The study is aimed to investigate the effect of honey and different levels of coconut flour on muffins. Four types of muffins such as, $\mathrm{T}_{1}-0 \%, \mathrm{~T}_{2}-5 \%, \mathrm{~T}_{3}-15 \%$ and $\mathrm{T}_{4} 25 \%$ of coconut flour incorporation were investigated and $\mathrm{T}_{4}$ is found more acceptable in terms of physicochemical properties of muffins. $\mathrm{T}_{4}$ muffins secured the highest score in color, texture and overall acceptability. The results showed that the addition of $25 \%$ coconut flour to the batter has improved the sensory and physico-chemical characteristics of the samples of the muffins obtained, and consequently increased their nutritional value.

\section{Introduction}

A Muffin is an individual-sized, baked product. Muffins are sweet baked products highly appreciated by consumers because of their soft texture and characteristic taste.

Coconut (Cocos nucifera) is one of the major nut/drupes. India is the 3rd largest coconut producing country in the world. It is very rich in fibre vitamins and minerals. Improves digestion, absorption of nutrients, vitamins and minerals. Coconut flour, a significant byproduct of coconut milk. Coconut flour was obtained by extraction of virgin oil from expeller, the residue left after virgin oil extraction was ground to obtain flour. Coconut flour may play a role in controlling cholesterol and sugar levels in blood and prevention of colon cancer. Studies revealed that consumption of high fibre coconut flour increases faecal bulk (Arancon., 1999).

Honey is a sweet, viscous food substance made by bees and some related insects. Bees produce honey from the sugary secretions of plants (floral nectar) or from secretions of other insects (such as honeydew), by regurgitation, enzymatic activity, and water evaporation. Bees store honey in wax 
structures called a honeycomb. Honey is one of the major nectars which contains protein, vitamins and minerals. It Strengthens the Immune system, Nourishes the skin and face and Boosts the memory. Honey gets its sweetness from the monosaccharide's fructose and glucose, and has about the same relative sweetness as sucrose (granulated sugar). It has attractive chemical properties for baking and a distinctive flavour when used as a sweetener. Most microorganisms do not grow in honey, so sealed honey does not spoil, even after thousands of years. Honey has an anti-bacterial agent (Jasmine, 2016). In addition, Dina (2017) said that the use of honey in food production would improve nutrition, appearance and taste. Honey contains 33 calories higher than sugar; in 1 tablespoon honey has 64 calories if compared to sugar that only has 48 calories (Shieh and Shieh, 2012). Honey give the sweet remedy for microbial diseases. The honey is an important part of traditional medicinal system which was used from older days to present days by all categories of peoples (Kalidasan et al., 2017).

It appeals to people as honey involves no white sugar and to those who watch their sugar intake. It has attractive chemical properties for baking, and a distinctive flavor which leads some people to prefer it over sugar and other sweeteners.

Wheat is the most widely cultivated cereal crop in the world and mainly used for milling and baking. Some wheat varieties (e.g. Triticum aestivum) are suitable for bread making while others (e.g. Triticum durum) are suitable for biscuits and cooking making. In recent years, bakery and confectionary products are fortified with various nutrients to enrich them to become a complete food with all necessary nutrients. The base material used for the preparation of bakery and confectionary products
Wheat flour is a vehicle for vitamins and minerals and an important source of carbohydrates, fibre, magnesium, vitamins B. folic acid, antioxidants and plant chemicals.

Eggs serve many functions in baked goods. They add flavor and color, contribute to structure, incorporate air when beaten, provide liquid, fat, and protein, and emulsify fat with liquid ingredients. Reducing or omitting egg yolks can result in less tenderness. Reducing or omitting egg whites can result in less volume. Cakes made without the emulsifying action from the egg yolk may not have a uniform flavor and texture.

This present study was thus undertaken with the objective of utilizing coconut flour for human consumption as a source of dietary fibre and protein.

Development of muffins by addition of coconut flour, honey along with sugar and its formulation

To assess the effect of added coconut flour and honey to muffins on sensory and nutritional characteristics.

To enhance the nutritive value of finished product in order fulfil the nutritional demand.

\section{Materials and Methods}

\section{Raw Materials}

The ingredients like Wheat flour, Honey, icing sugar, Melted Butter, baking soda, egg were procured from the local market Hassan city.

The experiment was at college of Agriculture, Hassan to study the effect of incorporation of different levels of four formulations were prepared by mixing wheat flour and coconut flour in the ratio of 50:0, 45:5,35:15 and 50:25and coded as $\mathrm{T}_{1}, \mathrm{~T}_{2}, \mathrm{~T}_{3}$ and $\mathrm{T}_{4}$ respectively. 


\section{Coconut flour preparation}

Five hundred grams $(500 \mathrm{~g})$ of coconuts were selected. As shown in Fig. 1 the coconuts were de-husked and the liquid drained. The thin layer of brown skin was removed, and the meat cut into smaller pieces using a knife. It was then transferred into a liquidizer containing $0.5 \mathrm{~L}$ of boiling water and was blended for $5 \mathrm{~min}$, until the pulp was smooth. The milk was separated from the meal using cheesecloth. The meal was washed again in hot $\left(100^{\circ} \mathrm{C}\right)$ water to reduce the oil content. The residue obtained was then weighed and dried using Hot Air Oven Dryer at $60^{\circ} \mathrm{C}$ until a constant weight was attained. The dried coconut was then milled into flour using plate mill. The coconut flour was sieved using a $100 \mu \mathrm{m}$ mesh sieve. The flour obtained was stored in polyethylene bags at room temperature and was used for the preparation of the muffins.

Formulation and Preparation of muffins with incorporation of Coconut Flour and Honey

The basic formulation of muffins are wheat flour $(50 \mathrm{~g})$, honey $(5 \mathrm{ml})$, powdered sugar $(45 \mathrm{~g})$, melted butter $(50 \mathrm{~g})$, baking powder $(1.5 \mathrm{~g})$ and egg $(35 \mathrm{~g})$. The replacements of wheat flour in the formulations are made with $5 \%, 15 \%$ and $25 \%$ of coconut flour and it is recognized as $\mathrm{T}_{1}$ Control (without coconut flour), $\mathrm{T}_{2}$ containing $5 \%$ coconut flour and $5 \mathrm{ml}$ honey, $\mathrm{T}_{3}$ containing $15 \%$ coconut flour and $5 \mathrm{ml}$ honey and $\mathrm{T}_{4}$ containing $25 \%$ coconut flour and $5 \mathrm{ml}$ honey. Baking powder were added to the mixture of wheat flour and coconut flour and other ingredients for each muffins were weighed accurately and the sugar and melted butter were mixed in a mixing machine for 20 minutes to produce a cream. In later stages, half of the water, egg and other ingredients and finally the flour were mixed using a mixer at low speed (145 rpm) for 10 minutes to ensure even distribution of the components. The bowl was scrapped and batter was mixed for an additional two minutes at medium speed (250 $\mathrm{rpm})$. The remaining water was added and the batter mixed at low speed for two minutes. The batter was placed into aluminium pans, previously oiled and covered with a butter paper and baked in a Hot-air oven pre-heated to $180{ }^{\circ} \mathrm{C}$ for $25-30$ minutes. After cooling, the muffins were weighed in order to calculate the total muffins yield and packed into LDPE bags and kept in a refrigerator at $5^{\circ} \mathrm{C}$ for further Sensory Evaluation and chemical analysis.

\section{Sensory Evaluation of Standardized muffins}

Evaluation of texture involves measuring the response of a food when it is subjected to forces such as cutting, shearing, chewing, compressing, or stretching. Food texture depends on the rheological properties of the food. Subjective measurement of texture gives an indirect evaluation of the rheological properties of a food (Ugwuona, et al., 2012).

The control sample and samples of muffins prepared with addition of different levels of coconut flour and equal quantity of honey were evaluated by fifteen panellists for the sensory qualities of colour, aroma, taste, texture and overall acceptability using a 9Point Hedonic Scale. Sample with highest acceptability was awarded a score of 9 and 1 for the least acceptable. The mean value of the scores from fifteen panellists was then calculated. The most acceptable muffins will be analysed for nutrient components.

\section{Proximate analysis}

The Nutritive value of the ingredients were analysed by standard AOAC methods. The control and formulated muffins samples i.e 
moisture content was determined adopting AOAC 2010. About $5 \mathrm{~g}$ sample was taken in a pre-weighted crucible, which was previously heated to $130^{\circ} \mathrm{C}$. The sample was dried for 1 hour in an air oven $130 \pm 3^{\circ} \mathrm{C}$. The loss of weight from sample was determined and calculated the moisture content. Protein, ash, fat and crude fiber were determined using AOAC. Total carbohydrate content of the sample was determined as total carbohydrate by difference, which is by subtracting the measured protein, fat, ash and moisture from $100 \mathrm{~g}$.

\section{Evaluation of physical properties}

Measurement of Weight, Height, Volume and Density: The muffins was weighed after cooling at room temperature for an hr. using weighing balance and the reading (g) was recorded. The height $(\mathrm{cm})$ of muffins was measured using ruler. Three measurements were taken from different sides of muffins. The average of the three points was recorded. The volume $\left(\mathrm{cm}^{3}\right)$ of muffins was determined 3 using rapeseed displacement method as described in the AACC method. The seeds were poured into an empty container to measure its volume. The rapeseeds in the container then measured in a measuring cylinder and marked as A. Subsequently, the muffins was placed into a same container and rapeseeds were poured in until the muffins was covered. The rapeseeds were again measured in a measuring cylinder and marked as $B$. The volume of the muffins was calculated by subtracting the value of A to B. The density $\left(\mathrm{g} / \mathrm{cm}^{3}\right)$ of the sample was calculated by 3 dividing weight $(\mathrm{g})$ of sample with volume $\left(\mathrm{cm}^{3}\right)$.

\section{Statistical Analysis}

Statistical Analysis was done using computer software. The analysis was done by application of ANOVA at 5\% significance level.

\section{Results and Discussion}

\section{Chemical composition of coconut flour}

Chemical compositions of coconut flour were showed in Table II. Results indicated that, obtained coconut flour was rich in lipid and fiber. Contents of lipid, protein, and fiber in coconut flour were $25.73,10.77$, and $20.92 \%$ w/w, respectively. Gunathilake (2008) reported that those of by product from extraction of coconut oil by screw extruder were 9.20, 12.60 and 13.20, respectively. However, in residue of coconut milk extraction, the contents of lipid, protein, and fiber were of 42.60, 4.20 and 23.2, respectively Masoodi, et al., 1998. These results indicated that compositions of coconut flour were influenced by the kinds of products manufactured from coconut endosperm. And, coconut flour contained the highly valuable components, such as: fiber, lipid, protein etc. which could be used for food.

\section{Sensory Evaluation of muffins}

The mean scores for sensory evaluation of $T_{1}$, $\mathrm{T}_{2}, \mathrm{~T}_{3}$ and $\mathrm{T}_{4}$, samples are shown in Table III. Sample $\mathrm{T}_{4}$, containing $25 \%$ coconut flour and 5 mlhoney had the highest scores for colour, texture, aroma, taste and the overall acceptability. While the increased protein and fat content through the addition of increase in quantity of coconut flour seems to have contributed to improvements in colour, aroma and taste. By addition of coconut flour and honey play important role in sponginess and higher overall acceptability of the finished product.

Kawai, et al., (2016), each type of cake has a different texture, aroma, and flavor. It depends on the ingredients, the processing, and the level of maturity. Texture, aroma, and flavor of cake give an effect to the quality of the cake which ultimately and it cause the 
effects of consumer acceptance of the cake. Some kind of cake texture are: soft, chewy, wet, and watery. While some kind of aroma are: weak, average, and strong. Then some kind of flavor are: salty, sweet, and spicy.

A slight low acceptable taste was observed in samples $\mathrm{T}_{1}, \mathrm{~T}_{2}$ and $\mathrm{T}_{3}$ containing $0 \%, 5 \%$ and $15 \%$ of coconut flour respectively. The scores for these samples for colour and aroma were also lower than the sample $\mathrm{T}_{4}$ containing $25 \%$ coconut flour and $5 \mathrm{ml}$ of honey. Sample $\mathrm{T}_{4}$, which was more acceptable than the other three samples containing coconut flour and honey was then compared with the control sample for its physical properties and chemical composition. Partial substitution of wheat flour with other flours causes significant changes in terms of texture, flavor, color, appearance and overall acceptability of the obtained products. Cummings et al., 2001. Kobkarn Namsirilert et al., 2015 result revealed that up to $40 \%$ replacement of coconut flour is possible to produce carrot cake with acceptable sensory quality.

\section{Proximate Analysis of muffins}

The control ( $0 \%$ of coconut flour and honey) sample and sample containing 5\%, 15\% and $25 \%$ coconut flour and 5mlhoney $\mathrm{T}_{2}, \mathrm{~T}_{3}$ and $\mathrm{T}_{4}$ respectively. Were analysed for the contents of moisture, protein, fat, ash, crude fibre, iron, calcium and phosphorous by the methods of AOAC. The results of analysis are shown in Table IV. The sample $\mathrm{T}_{4}$ was found to contain higher moisture content possibly due to the higher crude fibre content binding more amount of water in the muffins. The protein content was significantly higher because of the added higher amount $(25 \%)$ of coconut flour sample $\mathrm{T}_{4}$. The amount of water absorption decreases as the level of substitution incorporation of coconut flour revealed that oil seed flour added to wheat flour increased the water absorption. Increase in protein, fat, fiber and energy valves as the gradually increase in addition of coconut flour. Lower values were observed in the Carbohydrates, calcium, iron, phosphorous and moisture by gradual increase in addition of coconut flour to the product.

The use of a substitute for wheat flour affects the nutritive value of the product. Thus the partial substitution of wheat flour by nonwheat flours, such as coconut flour, slightly increases the protein content. cereal protein, including wheat, is limited in lysine content and they also recommended that the biological value of wheat flour can be significantly improved by the addition of lysine. Boceta, as cited by Barrett et.al (2004), stated that coconut flour when incorporated into wheat flour increases the amino acid content, especially lysine. Therefore, incorporation of coconut flour into wheat flour improves the protein content of composite flour and thus improves the nutritional status of food items such as bakery products made from that composite flour.

\section{Physical Properties and Texture Profile of muffins}

Table IV presented the results for physical properties (weight, height, volume and density) of muffins. There was a significant increase in the weight of muffins in the sample $\mathrm{T}_{1}$ (41.31g), $\mathrm{T}_{2}(40.30 \mathrm{~g}) \mathrm{T}_{3}(39.92 \mathrm{~g})$ compared with $\mathrm{T}_{4}(38.12 \mathrm{~g})$. However, as the incorporation level increases there will be significant increase in volume $\left(81.67 \mathrm{~cm}^{3}\right)$ and height $(4.89 \mathrm{~cm})$ of the muffins $\left(\mathrm{T}_{4}\right)$ compared to control sample. When there is increase in volume in the muffins it will gradually decreases the density in all the samples.

The cake volume produced with $100 \%$ of coconut flour had the least $(21.4 \pm 0.1 \mathrm{ml})$ as compared to that of the $100 \%$ wheat flour $(26.3 \pm 0.2 \mathrm{ml})$ and that of $50 \%$ coconut flour 
and $50 \%$ wheat flour composite flour $(24.3 \pm$ $0.5 \mathrm{ml})$. The cake volume increased significantly $(\mathrm{P}<0.05)$ in wheat flour samples as compared to coconut wheat composite flour samples and that of the coconut flour samples. (Newlove, et al., 2019)

Neha Kharkwal et al., 2018, A decrease in volume was observed in the muffins in which sugar was replaced in combination with stevia, jaggery and honey as compared to control. A significant decrease in specific volume was observed from 1.95 for control muffins to 1.89 for the muffins in combination with stevia jaggery and honey. The results can be correlated with the physical observation that samples become tougher with sugar replacement.
The influence of particles sizes on hydration properties of coconut flour; including: water absorption capacity (WAC), water retention capacity (WRC) and swelling capacities (SC); and oil binding capacity was significant. Specifically, WAC and SC values were positively related to the particle sizes of coconut flour. In particle sizes from $<0.18$ $\mathrm{mm}$ to $0.20-0.25 \mathrm{~mm}$, WRC has the same correlation; however, in particle sizes from 20-25 $\mathrm{mm}$ to $>0.45 \mathrm{~mm}$, it negatively related to particles sizes. Whereas, oil binding capacity $(\mathrm{OBC})$ value decreased with increase in particle sizes of flour. Adding coconut flour into dough caused increase in adhesiveness, hardness and cohesiveness, but insignificantly affected on springiness (Lai Quoc Dat and Vo Thi Hong Phuong, 2017).

Table.1 Different formulations of muffins by incorporation of coconut flour

\begin{tabular}{|l|c|c|c|c|}
\hline Treatments & $\mathbf{T}_{\mathbf{1}}$ & $\mathbf{T}_{\mathbf{2}}$ & $\mathbf{T}_{\mathbf{3}}$ & $\mathbf{T}_{\mathbf{4}}$ \\
\hline Wheat flour $(\mathbf{g})$ & 50 & 45 & 35 & 25 \\
\hline Coconut flour $(\mathbf{g})$ & - & 5 & 15 & 25 \\
\hline Honey $(\mathbf{m l )}$ & - & 5 & 5 & 5 \\
\hline Powdered sugar $(\mathbf{g})$ & 45 & 45 & 45 & 45 \\
\hline Butter $(\mathbf{g})$ & 50 & 50 & 50 & 50 \\
\hline Baking powder $(\mathbf{g})$ & 1.5 & 1.5 & 1.5 & 1.5 \\
\hline Egg(g) & 35 & 35 & 35 & 35 \\
\hline
\end{tabular}

Table.2 Nutritional Composition of wheat flour, coconut flour and honey were analysed using AOAC methods

\begin{tabular}{|l|c|c|c|}
\hline Ingredients & Wheat flour & Coconut flour & Honey \\
\hline Moisture (\%) & 13.30 & 7.20 & 20.6 \\
\hline Protein (\%) & 11.00 & 10.77 & 0.30 \\
\hline Fat (\%) & 0.90 & 25.73 & 0.00 \\
\hline Ash (\%) & 0.60 & 1.15 & 0.20 \\
\hline Fiber (\%) & 0.30 & 20.92 & 0.00 \\
\hline Iron (mg) & 2.70 & 0.10 & 0.69 \\
\hline Carbohydrates (g) & 73.90 & 55.15 & 79.50 \\
\hline Calcium (mg) & 23.00 & 0.31 & 5.00 \\
\hline Phosphorous (mg) & 121.00 & 0.41 & 16.00 \\
\hline Energy (kcal) & 348.00 & 474.74 & 319.00 \\
\hline
\end{tabular}


Table.3 Mean scores for the sensory evaluation of muffins

\begin{tabular}{|l|c|c|c|c|}
\hline Sensory qualities & $\mathbf{T}_{\mathbf{1}}$ & $\mathbf{T}_{\mathbf{2}}$ & $\mathbf{T}_{\mathbf{3}}$ & $\mathbf{T}_{\mathbf{4}}$ \\
\hline Colour & 8 & 6 & 7 & 9 \\
\hline Texture & 8 & 7 & 6 & 9 \\
\hline Taste & 8 & 6 & 8 & 9 \\
\hline Aroma & 7 & 7 & 8 & 9 \\
\hline $\begin{array}{l}\text { Overall } \\
\text { acceptance }\end{array}$ & 7 & 6 & 8 & 9 \\
\hline
\end{tabular}

Note; 9: Like extremely 8: Like very much 7: Like moderately 6: Like slightly 5: Neither like nor dislike 4: Dislike slightly 3: Dislike moderately 2: Dislike very much 1: Dislike extremely

Table.4 Chemical composition of coconut flour and honey incorporated muffins

\begin{tabular}{|l|c|c|c|c|}
\hline Parameters & $\mathbf{T}_{\mathbf{1}}$ & $\mathbf{T}_{\mathbf{2}}$ & $\mathbf{T}_{\mathbf{3}}$ & $\mathbf{T}_{\mathbf{4}}$ \\
\hline Moisture (\%) & 20.00 & 19.80 & 19.30 & 18.70 \\
\hline Protein (\%) & 8.80 & 10.40 & 10.70 & 10.90 \\
\hline Fat (\%) & 15.00 & 18.10 & 18.40 & 18.70 \\
\hline Ash (\%) & 1.62 & 1.68 & 1.73 & 1.77 \\
\hline Fiber (\%) & 0.30 & 1.00 & 3.00 & 5.10 \\
\hline Iron (mg) & 1.40 & 1.30 & 0.95 & 0.74 \\
\hline Carbohydrates (g) & 55.58 & 50.02 & 49.87 & 49.93 \\
\hline Calcium (mg) & 45.00 & 43.25 & 40.02 & 38.03 \\
\hline Phosphorous(mg) & 68.00 & 65.23 & 62.20 & 60.09 \\
\hline Energy (kcal) & 392.52 & 404.00 & 407.88 & 411.62 \\
\hline
\end{tabular}

Table.4 Physical properties of muffins

\begin{tabular}{|l|c|c|c|c|}
\hline \begin{tabular}{l} 
Parameter \\
\multicolumn{1}{|c|}{ Physical properties }
\end{tabular} & $\mathbf{T}_{\mathbf{1}}$ & $\mathbf{T}_{\mathbf{2}}$ & $\mathbf{T}_{\mathbf{3}}$ & $\mathbf{T}_{\mathbf{4}}$ \\
\hline Weight $(\mathbf{g})$ & $41.31 \pm 0.75$ & $40.30 \pm 0.45$ & $39.92 \pm 0.17$ & $38.12 \pm 0.03$ \\
\hline Height $(\mathbf{c m})$ & $3.44 \pm 0.22$ & $3.68 \pm 0.58$ & $4.10 \pm 0.78$ & $4.89 \pm 0.99$ \\
\hline Volume $\left(\mathbf{c m}^{\mathbf{3}}\right)$ & $78.03 \pm 0.73$ & $79.04 \pm 0.57$ & $80.22 \pm 1.03$ & $81.67 \pm 1.50$ \\
\hline Density $\left(\mathbf{g} / \mathbf{c m}^{\mathbf{3}}\right)$ & $0.53 \pm 0.73$ & $0.51 \pm 0.57$ & $0.49 \pm 1.04$ & $0.47 \pm 1.53$ \\
\hline
\end{tabular}

Fig.1 Flow chart for the production of coconut flour

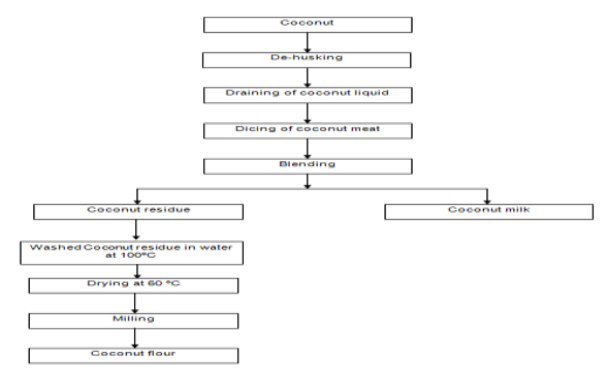


Fig.2 Preparation of muffins



Graph.1 Representation of Chemical composition of coconut flour and honey incorporated muffins

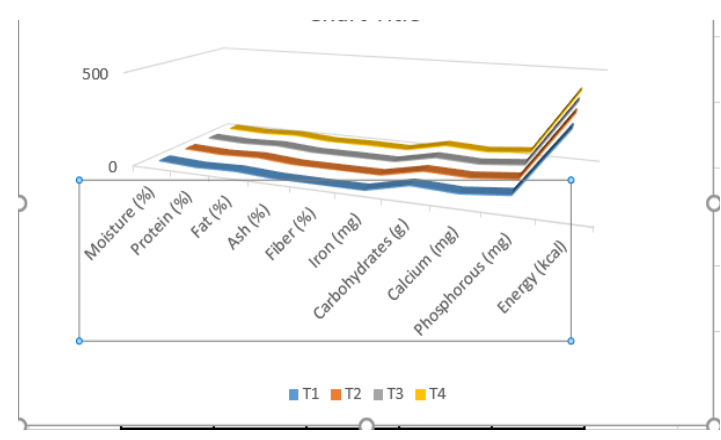

\section{Effect of honey on the muffin quality}

Sugar in the muffin formulation was replaced by honey as a sugar replacer at $5 \%$ on weight basis (Table I). In addition of honey to the formulated muffins resulted in the increase in volume of the product. The organoleptic evaluation of the muffins showed the significant variation in the various parameters such as colour, texture, flavour and overall acceptability of muffins. In case of muffins substituted with honey, significant variations were observed for colour, texture, flavour and overall acceptability compared to control. According to Neha Kharkwal, et al., 2018 The overall acceptability of 20 percent honey substituted muffins was highest followed by 30 percent honey substituted muffins. The least acceptable muffins were in which 50 percent sugar was replaced by honey in terms of all the parameters.
In conclusion this study confirmed that incorporation of different levels of coconut flour to the muffins formulation has improved the muffins quality attribute nutritionally protein, minerals, fat and crude fiber and physically flavor, color, texture, volumeand weight. The present study confirmed that the blending of wheat flour with coconut flour at different levels altered the organoleptic and rheological properties of different blends, even though it is acceptable up to $25 \%$ fortification level. It is therefore concluded that adding up to $25 \%$ coconut flour actually gives organoleptically acceptable muffins. Fortification with coconut flour is advantageous due to the increased nutritional value, as coconut flour is rich in protein and dietary fibre. Based on the outcomes of the studies, it was concluded that low cost muffns can be prepared by replacing sugar with other 
natural sweetener like honey as a bulking agent. Also, by correlating the results obtained, it can be appreciated that established recipes from this study can be successfully applied on an industrial scale.

\section{References}

AB Khatkar Ph. D Scholar, College of Food Processing Technology and BioEnergy Anand Agricultural University, Anand, Gujarat, India.

Amarjeet Kaur Sr. Milling Technologist, College of Food Processing Technology and Bio- Energy Anand Agricultural University, Anand, Gujarat, India

Arancon, R.N. (1999). Coconut flour. Cocoinfo International, 6(1), 1-8.

Barrett, D.M., Somogyi, L.P. and Ramaswamy, H.S. (2004). Processing Fruits: Science and Technology, 2nd Edition, CRC Press

Bawalan, D.D. (2000). The economics of production, utilization and marketing of coconut flour from coconut milk residue. CORD, XVI(1), 1-13.

Correspondence Neha Kharkwal Ph. D Scholar, College of Food Processing Technology and Bio- Energy Anand Agricultural University, Anand, Gujarat, India.

Cummings, J.H., The effect of dietary fiber on fecalweight and composition. In: Spiller G, ed. Dietary Fiber in Human Nutrition, 2001, Boca Raton, FL: CRC Press, 183-252.

Dina (2017): Serba-Serbi Penggunaan Madu Dalam Masakan. [Internet: http://sajiansedap.grid.id/Info/serbaserbi-penggunaan-madudalammasakan

Gunathilake K.D.P.P. *, C. Yalegama and A.A.N. Kumara.(2009), Use of coconut flour as a source of protein and dietary fibre in wheat bread. Asian
Journal of Food and Agro-Industry ISSN 1906-3040 Available online at www.ajofai.infoAs. J. Food Ag-Ind. 2009, 2(03), 386-395

Gunathilake, K.D.P.P, Abeyrathne, Y,M.R.K. (2008). Incorporation of coconut flour into wheat flour noodles and evaluation of its rheological, nutritional and sensory characteristics, Journal of Food Processing and Preservation, 32.133-142.

Hagenmaier, R. (1983). Dried coconut milk and other new foods from wet process. Coconuts Today, 1(1), 17-24. 18

Jasmine Nadia (2017): 8 Pemanis yang Lebih Sehat Sebagai Pengganti Gula Tebu. [Internet:

https://cantik.tempo.co/read/news/2016 /11/17/332820942/8pemanis-yanglebih-sehat-sebagai-pengganti-gulatebu“15 Agustus 2017']

Jaspreet Kaur Assistant Food Technologist, College of Food Processing Technology and Bio- Energy Anand Agricultural University, Anand, Gujarat, India

Kalidasan, G., Saranraj, P., Ragul, V. and Sivasakthi, S. 2017. Antibacterial activity of Natural and Commercial Honey-A comparative study. Adv. Biolog. Res. 11(6): 365-372

Kawai, K., K. Hando, R. Thuwapanichayanan, and Y. Hagura. 2016. Effect of stepwise baking on the structure, browning, texture, and in vitro starch digestibility of cookie. LWT-Food Science and Technology 66:384-89.

Kobkarn Namsirilert1, Sriwatana Songchitsomboon1,* and Surat Komindr2.(2015). Effect of replacing wheat flour with coconut flour to carrot cake on in vitro starch digestion rate and sensory evaluation. Food and Applied Bioscience Journal, 2015, 3 (3): 206-215 
Lai Quoc Dat*, Vo Thi Hong Phuong.(2017).FUNCTIONAL PROPERTIES AND INFLUENCES OF COCONUT FLOUR ON TEXTURE OF DOUGH AND COOKIES, Faculty of Chemical Engineering, University of Technology, VNU-HCM 268 Ly Thuong Kiet str., 10 dist., Ho Chi Minh city, Vietnam Journal of Science and Technology 55 (5A) 100-107

Marquez, P.O. (1979). Nutritional advantages of Philippine coconut flour. Coconut Farmers Bulletin, 4, 1-7.

Masoodi, F.A. and Chauhan, G.S. (1998). Use of apple pomace as a source of dietary fiber in wheat bread. Journal of Food Processing and Preservation, 22 (1998), 255-263

Neha Kharkwal, Amarjeet Kaur, Jaspreet Kaur and AB Khatkar.(2018). Quality evaluation of muffins prepared by replacing sugar with natural sweeteners (Special Issue -4) International Conference on Food Security and Sustainable Agriculture. P-ISSN: 2349-8528 E-ISSN: 23214902 IJCS 2018; SP4: 175-180.

Newlove A. Afoakwah1*, John Owusu2 and
Victoria Owusu3. (2019) Characteristics of Coconut (Cocos nucifera) Flour and Its Application in Cake, Asian Food Science Journal 13(1): 1-11, 2019; $\quad$ Article no.AFSJ.44476 ISSN: 2581-7752

Richa Singh (2016) Development of fiber enriched bakery products by incorporating fruit pulp waste powder and their acceptability evaluation. Int. J. Adv. Res. Biol. Sci. 3(6): 222-226

Shieh, M. and Shieh, M. (2012): Getting Healthy with the DeVIP System. Trafford Publishing, Canada

Trinidad, P.T., Mallillin, A.C., Valdez, D.H., Loyola, A.S., Askali-Mercado, F.C., Castillo, J.C., Encabo, R.R., Masa, D.B., Maglaya, A.S. and Chua, M.T. (2006), Dietary fiber from coconut flour: A functional food. Innovative Food Science and Emerging Technologies, 7: 309-317.

Ugwuona, F.U, Ogara, J.L and Awogbenja, M.D (2012): Chemical and sensory quality of cakes formulated with wheat, soybeans and cassava flours, Indian Journal.L. Sci. 1 (2):1-6

\section{How to cite this article:}

Ramya, H. N. and Anitha, S. 2020. Development of Muffins from Wheat Flour and Coconut Flour using Honey as a Sweetener. Int.J.Curr.Microbiol.App.Sci. 9(07): 2231-2240. doi: https://doi.org/10.20546/ijcmas.2020.907.260 